\title{
PENGARUH FINANCIAL BEHAVIOR, FINANCIAL ATTITUDE, DAN FINANCIAL CAPABILITY TERHADAP FINANCIAL SATISFACTION
}

\author{
Candra Wijaya dan Ary Satria Pamungkas \\ Program Studi Manajemen Fakultas Ekonomi dan Bisnis Universitas Tarumanagara Jakarta \\ Email: candrawjy1999@gmail.com
}

\begin{abstract}
The purpose of this research is toexamine the effect of Financial Behavior, Financial Attitude and Financial Satisfaction. The samples of this study is the people of Riau who are already working. The sample was selected by convenience sampling method amounted to 165 respondent with an online questionnaire help by Google form. The data analysis technique used is structural equation modeling assisted bu the SmartPLS program. The result of this study show that there is an influence of Financial Behavior, Financial Attitude, and Financial Capability on Financial Satisfaction.

Keywords: Financial Behavior, Financial Attitude, Financial Capability, Financial Satisfaction

Abstrak: Tujuan dari penelitian ini adalah untuk menguji pengaruh Financial Behavior, Financial Attitude terhadap Financial Satisfaction. Sampel penelitian ini adalah masyarakat Riau yang sudah bekerja. Sampel dipilih dengan metode convenience sampling berjumlah 165 responden dengan bantuan kuisioner online bantuan Google Form. Teknik analisis data yang digunakan adalah Structural equation modelling yang dibantu program SmartPLS. Hasil penelitian ini menunjukkan bahwa terdapat pengaruh Financial Behavior, Financial Attitude, dan Financial Capability terhadap Financial Satisfaction.
\end{abstract}

Kata kunci: Tingkah Laku Finansial, Sikap Finansial, Kemampuan Finansial, Kepuasan Finansial

\section{LATAR BELAKANG}

Zimmerman (1995) mengemukakan kesejahteraan (well-being) dapat diartikan sebagai keadaan dimana seseorang merasa nyaman dan bahagia. Veenhoven (2011) mengatakan bahwa kebahagiaan bisa juga disebut sebagai kepuasan hidup. Kepuasan hidup memiliki hubungan yang erat terhadap kesejahteraan (well-being) karena seseorang yang Bahagia pada akhirnya akan mencapai titik kepuasan hidup yang mengganggap dirinya sudah menjadi lebih sejahtera.

Salah satu aspek dalam kesejahteraan (well-being) adalah kesejahteraan finansial (financial well-being), dimana adanya rasa puas yang dirasakan seseorang terhadap status keuangannya. Dalam mencapai kesejahteraan finansial (financial well-being) tersebut, perlu diketahui adanya aspek yang cukup mempengaruhinya yaitu kesehatan finansial (financial wellness). Kesehatan 
finansial (financial wellness) merupakan suatu konsep yang menggabungkan kepuasan finansial, sikap keuangan, dan toleransi resiko (Xiao, 2008).

Kepuasan finansial (financial satisfaction) dapat diartikan sebagai suatu ukuran subjektif dari kesejahteraan finansial (financial well-being) yang berarti tingkat kepuasan yang dirasakan oleh masing-masing individu yang berhubungan dengan aspek keuangan (Sahi, 2013). Semakin puas seseorang dengan kondisi keuangannya akan membuat individu tersebut akan semakin puas dan bahagiaan (Toscano et al., 2006).

\section{KAJIAN TEORI}

Menurut Joo dan Grable (2004) "Financial satisfaction and well-being include factor related to the material and non-material aspects of one's financial situation, including objective and subjective constructs. In general, financial satisfaction includes contentment with one's material (objective) and non-material (subjective) financial situation." disimpulkan bahwa kepuasan finansial meliputi aspek-aspek yang berhubungan dengan aspek material (objektif) dan aspek non material (subjektif) dari kondisi finansial seseorang.

Menurut Joo dan Grable (2004), "financial behavior can be explained by several factors. The first individual's behavior himself. The attitude and behavior of someone in financial field is called financial behavior" disimpulkan bahwa prilaku keuangan dipengaruhi oleh beberapa faktor seperti perilaku individu, sikap dan perilaku seseorang dibidang keuangan.

Menurut Yulianti dan Silvy (2013) "Financial attitudes could be influenced by routine activities and how a person sees the financial acts are considered as good or bad by looking to his own or others' perspective; though, financial experience also giving contribution here.." disimpulkan bahwa sikap keuangan dapat dipengaruhi oleh kegiatan seseorang dan bagaimana cara dia melihat tindakan keuangan yang dianggap baik maupun buruk dengan sudut pandangnya sendiri maupun orang lain. Arifin (2018) "Financial attitude is defined as a state of mind, opinion and judgment about finance." sikap keuangan dapat juga diartikan sebagai keadaan pikiran, pendapat serta penilaian tentang keuangan.

Menurut Taylor (2011) “Financial capability reflect people's knowledge of financial matter, theirs ability to manage their money and to take control of their finances." Dapat disimpulkan bahwa kemampuan keuangan mencerminkan pengetahuan seseorang terhadap masalah keuangan serta kemampuan mereka dalam mengelola dan mengendalikan keuangan mereka.

Kaitan antar Variabel. Menurut penelitian Arifin (2018) menyatakan adanya hubungan antara financial behavior terhadap financial satisfaction. Yang menunjukkan semakin baik prilaku keuangan seseorang akan menyebabkan semakin baik pula kepuasan orang tersebut akan keuangannya. Seseorang yang mampu memperlakukan keuangannya dengan baik, mengaturnya secara teratur dan menggunakan uangnya dengan bijak akan membuat orang tersebut mencapai financial satisfaction yang tinggi. 
Menurut penelitian Chandra dan Memarista (2015) menyatakan adanya hubungan antara financial attitude terhadap financial satisfaction. Jika seseorang memiliki financial attitude yang baik maka akan meningkatkan financial satisfaction orang tersebut.

Menurut Irwandi dan Firli (2020) terdapat hubungan antara financial capability terhadap financial satisfaction, dimana seseorang yang memiliki kemampuan finansial yang baik, seseorang yang dapat mencapai titik kesejahteraan finansial berarti orang tersbut juga sudah mencapai titik kepuasan finansial.

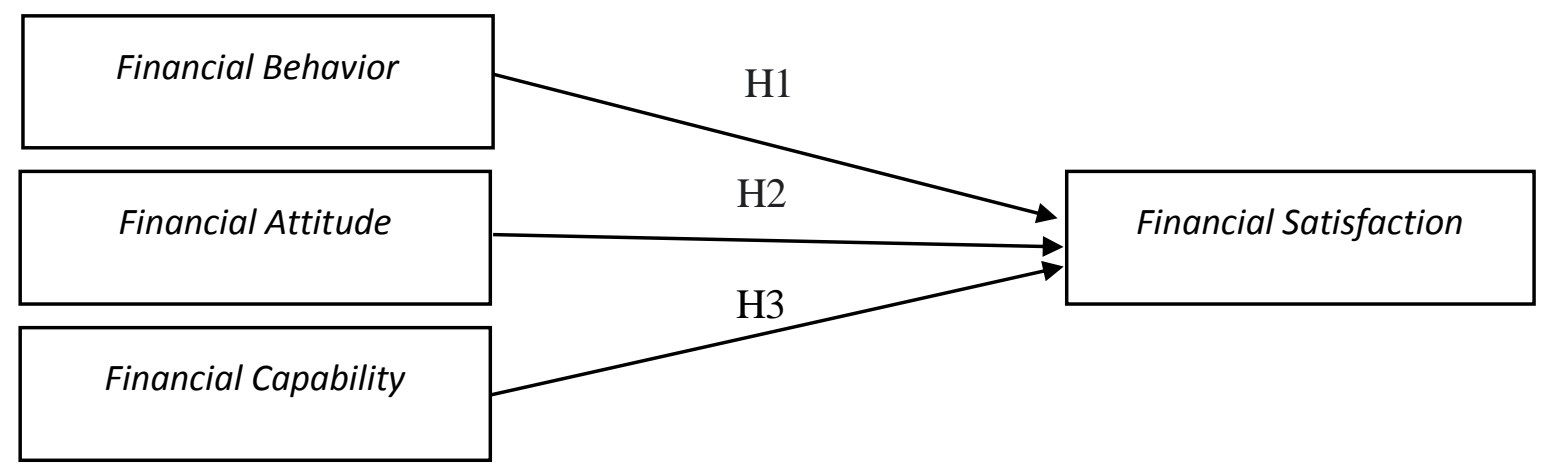

Hipotesis dari model kerangka pemikiran yang telah dibuat diatas adalah sebagai berikut:

H1 : Terdapat pengaruh financial behavior terhadap financial satisfaction.

H2 : Terdapat pengaruh financial attitude terhadap financial satisfaction.

H3 : Terdapat pengaruh financial capability terhadap financial satisfaction.

\section{METODOLOGI}

Populasi pada penelitian ini adalah seluruh masyarakat Riau yang sudah bekerja. Teknik yang digunakan dalam pemilihan sampel penelitian ini adalah dengan teknik convenience sampling dan didapat sampel sebanyak 165 responden yang berada di Riau. Pengumpulan sampel dibantu dengan bantuan google form yang disebarkan secara online. Teknik analisis data yang digunakan adalah structural equation modelling yang dibantu dengan program SmartPLS. Suatu model penelitian harus memenuhi syarat valid dan reliabel, sehingga pada penelitian ini model akan diuji validitas dan reliabilitasnya. Setelah sebuah model penelitian memenuhi persyarakan uji model pengukuran (outer model analysis) maka tahap selanjutnya adalah melakukan analisis model struktural (inner model analysis) penelitian kriteria-kriteria yang harus dipenuhi dalam analysis model struktural meliputi nilai koefisien determinasi $\left(\mathrm{R}^{2}\right)$, predictive relevance $\left(\mathrm{Q}^{2}\right)$, effect size $\left(\mathrm{f}^{2}\right)$ dan path coefficients.

Pada penelitian yang menggunakan PLS-SEM, maka pengujian hipotesis dilakukan dengan melihat nilai t-statistik dari sampel independen. 


\section{HASIL UJI STATISTIK}

Validitas dan Reliabilitas. Uji validitas pada penelitian ini dengan melihat nilai convergent validity dan discriminant validity. Convergent validity merupakan sejauh mana indikator dalam konstruk yang sama berkolerasi secara positif. Convergent validity dapat dilakukan dengan menghitungan nilai outer loading factor setiap indikator dan nilai average variance extracted (AVE). Tabel 1. menunjukan nilai AVE masing-masing variabel yang lebih besar dari 0,5 yang artinya memenuhi salah satu kriteria dari convergent validity

Tabel 1. Hasil analisis Average Variance Extracted (AVE)

\begin{tabular}{|c|c|}
\hline Variabel & Average Variance Extracted (AVE) \\
\hline Financial Behavior & 0.676 \\
\hline Financial Attitude & 0.566 \\
\hline Financial Capability & 0.601 \\
\hline Financial Satisfaction & 0.585 \\
\hline
\end{tabular}

Tabel 2. dan gambar 1. menunjukkan nilai loading factor masing-masing indikator pada tiap variabel yang diteliti. Nilai loading factor yang didapat menunjukan nilai diatas 0,7 yang artinya memenuhi kriteria dari convergent validity.

Tabel 2. Hasil Loading Factor

\begin{tabular}{|c|c|l|l|l|}
\hline Indikator & $\begin{array}{l}\text { Financial } \\
\text { Behavior }\end{array}$ & $\begin{array}{l}\text { Financial } \\
\text { Attitude }\end{array}$ & $\begin{array}{l}\text { Financial } \\
\text { Capability }\end{array}$ & $\begin{array}{l}\text { Financial } \\
\text { Satisfaction }\end{array}$ \\
\hline FB1 & 0.849 & & & \\
\hline FB2 & 0.862 & & & \\
\hline FB3 & 0.783 & & & \\
\hline FB4 & 0.791 & & & \\
\hline FA1 & & 0.733 & & \\
\hline FA2 & & 0.793 & & \\
\hline FA3 & & 0.751 & & \\
\hline FA4 & & 0.732 & & \\
\hline FC1 & & & 0.831 & \\
\hline FC2 & & & 0.779 & \\
\hline FC3 & & & 0.745 & \\
\hline FC4 & & & 0.742 & \\
\hline
\end{tabular}




\begin{tabular}{|c|l|l|l|c|}
\hline FS1 & & & & 0.728 \\
\hline FS2 & & & & 0.820 \\
\hline FS3 & & & & 0.746 \\
\hline FS4 & & & & 0.799 \\
\hline FS5 & & & & 0.725 \\
\hline
\end{tabular}

Gambar 1. Hasil Convergent Validity

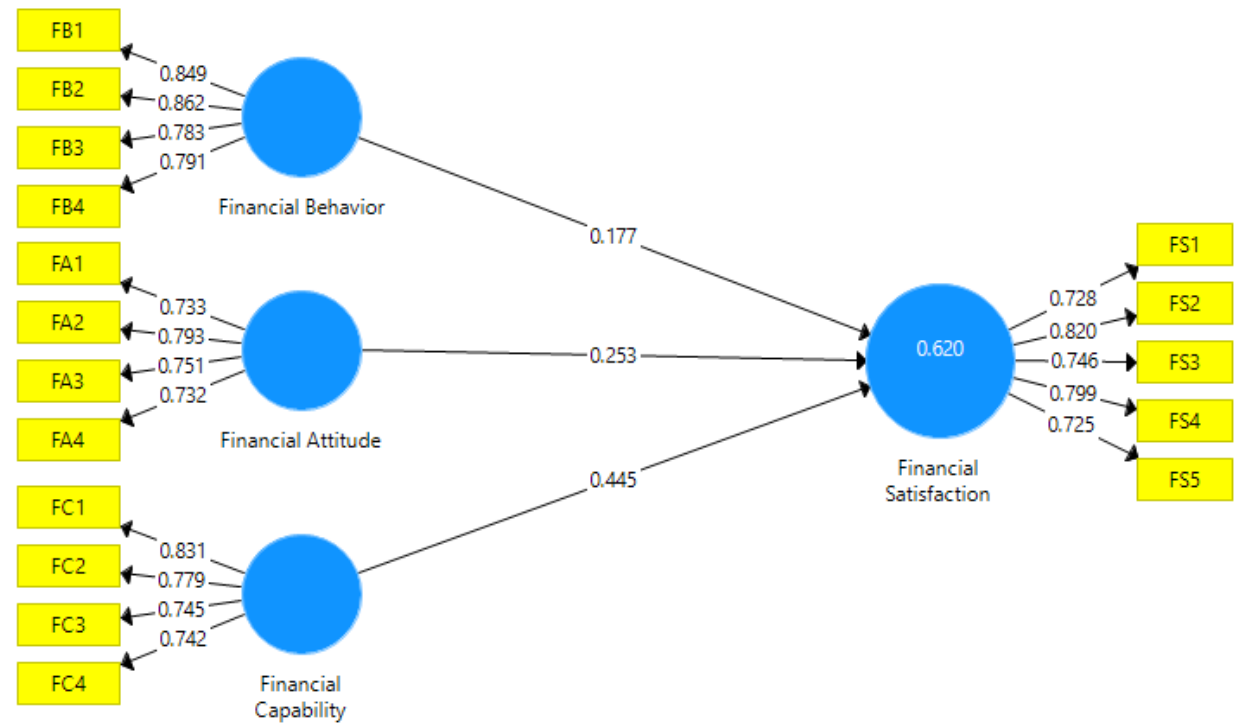

Suatu instumen dianggap valid dengan motode Fornell-Larcker, apabila nilai akar kuadrat AVE dari masing-masing konstruk lebih besar daripada korelasi dengan variabel laten lainnya. Demikian pula dengan pendekatan nilai cross loadings. Nilai loadings masing-masing indikator tersebut dalam konstruk lainnya. Berikut tabel 3. Menunjukkan hasil cross loadings dari setiap indikator

Tabel 3. Hasil nilai Cross Loading

\begin{tabular}{|c|c|c|c|c|}
\hline Indikator & $\begin{array}{l}\text { Financial } \\
\text { Behavior }\end{array}$ & $\begin{array}{l}\text { Financial } \\
\text { Attitude }\end{array}$ & $\begin{array}{l}\text { Financial } \\
\text { Capability }\end{array}$ & $\begin{array}{l}\text { Financial } \\
\text { Satisfaction }\end{array}$ \\
\hline FB1 & 0.849 & 0.597 & 0.596 & 0.595 \\
\hline FB2 & 0.862 & 0.513 & 0.594 & 0.584 \\
\hline FB3 & 0.783 & 0.467 & 0.516 & 0.463 \\
\hline FB4 & 0.791 & 0.615 & 0.539 & 0.476 \\
\hline
\end{tabular}




\begin{tabular}{|c|c|c|c|c|}
\hline FA1 & 0.530 & 0.733 & 0.506 & 0.483 \\
\hline FA2 & 0.510 & 0.793 & 0.527 & 0.551 \\
\hline FA3 & 0.507 & 0.751 & 0.511 & 0.552 \\
\hline FA4 & 0.461 & 0.732 & 0.590 & 0.506 \\
\hline FC1 & 0.545 & 0.575 & 0.831 & 0.625 \\
\hline FC2 & 0.495 & 0.557 & 0.779 & 0.562 \\
\hline FC3 & 0.627 & 0.588 & 0.745 & 0.533 \\
\hline FC4 & 0.465 & 0.479 & 0.742 & 0.585 \\
\hline FS1 & 0.348 & 0.483 & 0.536 & 0.728 \\
\hline FS2 & 0.517 & 0.545 & 0.629 & 0.820 \\
\hline FS3 & 0.501 & 0.452 & 0.553 & 0.746 \\
\hline FS4 & 0.574 & 0.585 & 0.570 & 0.799 \\
\hline FS5 & 0.527 & 0.548 & 0.557 & 0.725 \\
\hline
\end{tabular}

Tabel 3. Menunjukkan nilai cross loading masing-masing indikator yang diteliti pada penelitian ini. Nilai cross loading masing-masing indikator menunjukkan nilai yang lebih tinggi daripada nilai cross loadings indikator tersebut dalam konstruk lainnya. Maka kriteria dari discriminant validity dengan pendekatan nilai cross loading terpenuhi.

Tabel 4. Di bawah ini menunjukkan hasil analisis nilai Fornell-Larcker dari setiap variabel dalam penelitian.

Tabel 4. Hasil analisis Fornell-Larcker

\begin{tabular}{|c|c|c|c|c|}
\hline Variabel & $\begin{array}{c}\text { Financial } \\
\text { Attitude }\end{array}$ & $\begin{array}{c}\text { Financial } \\
\text { Behavior }\end{array}$ & $\begin{array}{c}\text { Financial } \\
\text { Capability }\end{array}$ & $\begin{array}{c}\text { Financial } \\
\text { Satisfaction }\end{array}$ \\
\hline Financial Attitude & 0.752 & & & \\
\hline Financial Behavior & 0.666 & 0.822 & & \\
\hline Financial Capability & 0.708 & 0.685 & 0.775 & \\
\hline Financial Satisfaction & 0.686 & 0.650 & 0.745 & 0.756 \\
\hline
\end{tabular}

Tabel 4. Menunjukkan nilai akar kuadrat AVE setiap variabel yang diteliti lebih besar dari korelasi antar variabel. Hasil tersebut menunjukkan bahwa kriteria dari analisis fornell-larcker pada discriminant validity terpenuhi.

Suatu instrument dinyatakan reliabel jika instrument tersebut memiliki nilai Cronbach's alpha dan composite reliability untuk setiap variabel lebih besar dari 0,6. Cronbach's alpha dan composite-reliability pada variabel yang diteliti akan disajikan pada tabel 5. di bawah ini. 
Tabel 5. Hasil Analisis Reliabilitas

\begin{tabular}{|c|c|c|}
\hline Variabel & Cronbach's Alpha & $\begin{array}{c}\text { Composite } \\
\text { Reliability }\end{array}$ \\
\hline Financial Behavior & 0.840 & 0.893 \\
\hline Financial Attitude & 0.744 & 0.839 \\
\hline Financial Capability & 0,778 & 0.857 \\
\hline Financial Satisfaction & 0.822 & 0.875 \\
\hline
\end{tabular}

Tabel 5. di atas menunjukkan nilai cronbach's alpha dan composite reliability masingmasing variabel yang diteliti memiliki nilai lebih besar dari 0,6. Maka variabel- variabel yang diteliti pada penlitian ini dapat dinyatakan reliabel.

Koefisien determinasi adalah ukuran dari akurasi prediksi sebuah model. Koefisien determinasi mewakili efek gabungan variabel eksogen pada variabel endogen, dengan kata lain koefisien determinasi bertujuan untuk melihat kontribusi variabel eksogen untuk memprediksi variabel endogen. Hasil koefisien determinasi akan ditampilkan pada tabel 6. di bawah ini.

Tabel 6. Hasil Pengujian Koefisien Determinasi $\left(\mathrm{R}^{2}\right)$

\begin{tabular}{|c|c|}
\hline Variabel & $R$ Square \\
\hline Financial Satisfaction & 0.620 \\
\hline
\end{tabular}

Tabel 6. menunjukkan hasil koefisien determinasi sebesar 0,620 yang berarti sebesar $62 \%$ dari variabel dependen yaitu financial satisfaction dapat dijelaskan oleh variabel indepeden pada penelitian ini dan sisanya sebesar 38\% dapat dijelaskan oleh variabel-variabel di luar penelitian ini. Nilai koefisien determinasi yang diperoleh tergolong moderat.

Tabel 7. Hasil Bootstrapping

\begin{tabular}{|c|c|c|c|}
\hline Variabel & $\begin{array}{c}\text { Path } \\
\text { Coefficient }\end{array}$ & $\begin{array}{c}t- \\
\text { statistics }\end{array}$ & $\begin{array}{c}p- \\
\text { Values }\end{array}$ \\
\hline Financial Behavior -> Financial Satisfaction & 0.177 & 2.012 & 0.045 \\
\hline Financial Attitude -> Financial Satisfaction & 0.253 & 3.033 & 0.003 \\
\hline Financial Capability -> Financial Satisfaction & 0.445 & 4.931 & 0.000 \\
\hline
\end{tabular}

Berdasarkan tabel 7. di atas, diperoleh persamaan dalam penelitian ini yaitu $\mathrm{FS}=0,177 \mathrm{FB}$ $+0,253 \mathrm{FA}+0,445 \mathrm{FC}$. Nilai path coefficient menunjukkan bahwa nilai prediksi variabel financial behavior terhadap financial satisfaction memiliki arah yang positif dengan nilai sebesar 0,177 ; nilai prediksi financial attitude terhadap financial satisfaction memiliki arah yang positif dengan nilai sebesar 0,253; nilai prediksi financial capability terhadap financial satisfaction memiliki arah yang positif dengan nilai sebesar 0.445 . 
Pengujian Hipotesis. Berdasarkan tabel 7. dapat dilihat bahwa nilai t-statistik financial behavior terhadap financial satisfaction sebesar 2,012 yang lebih besar dari nilai minimum yang ditetapkan sebesar 1,96 dan nilai p-value sebesar 0,045 lebih kecil dari nilai maksimum yang ditetapkan sebesar 0,05 sehingga dapat disimpulkan hipotesis pertama tidak ditolak.

Berdasarkan tabel 7. dapat dilihat bahwa nilai t-statistik financial attitude terhadap financial satisfaction sebesar 3,003 yang lebih besar dari nilai minimum yang ditetapkan sebesar 1,96 dan nilai $p$-value sebesar 0.003 yang lebih kecil dari nilai maksimum yang ditetapkan sebesar 0,05 sehingga dapat disimpulkan hipotesis kedua tidak ditolak.

Berdasarkan tabel 7. dapat dilihat bahwa nilai t-satistik financial capability terhadap financial satisfaction sebesar 4,931 yang lebih besar dari nilai minimum yang ditetapkan sebesar 1,96 dan nilai $p$-value sebesar 0,000 yang lebih kecil dari nilai maksimum yang ditetapkan sebesar 0,05 sehingga dapat disimpulkan hipotesis ketiga tidak ditolak.

\section{DISKUSI}

Pengaruh Financial Behavior terhadap Financial Satisfaction. Hasil Penelitian ini menunjukkan terdapat pengaruh yang signifikan dan positif financial behavior terhadap financial satisfaction, hal ini dapat dibuktikan dengan melihat nilai t-statistik financial behavior terhadap financial satisfaction yang sebesar 2,012 yang lebih besar dari nilai minimum yang ditentukan sebesar 1,96 dan nilai dari p-value yang sebesar 0,045 yang lebih kecil dari nilai maksimum yang ditetapkan sebesar 0,05, yang berarti semakin baik atau besar financial behavior seseorang, maka akan semakin besar juga tingkat financial satisfaction seseorang. Indikator yang paling berpengaruh adalah indikator mengenai pentingnya untuk mengatur keuangan serta memiliki anggaran pengeluaran yang baik.

Pengaruh Financial Attitude terhadap Financial Satisfaction. Hasil penelitian ini menunjukkan terdapat pengaruh yang signifikan dan positif financial attitude terhadap financial satisfaction. Hal ini dapat dibuktikan dengan melihat nilai t-statistik financial attitude terhadap financial satisfaction yang sebesar 3,033 yang lebih besar dari nilai minimum yang ditentukan sebesar 1,96 dan nilai $p$-value sebesar 0,003 yang lebih kecil dari nilai maksimum yang ditentukan sebesar 0,05, yang berarti semakin baik dan tinggi financial attitude seseorang, maka akan semakin tinggi juga financial satisfaction seseorang. Indikator yang paling berpengaruh adalah indikator tentang pentingnya uang, orang lebih memilih menginvestasikan uang mereka dibandingkan untuk dibelanjakan.

Pengaruh Financial Capability terhadap Financial Satisfaction. Hasil penelitian ini menunjukkan terdapat pengaruh yang signifikan dan positif financial capability terhadap financial satisfaction. Hal ini dapat dibuktikan dengan melihat nilai t-statistik financial capability terhadap financial satisfaction yang sebesar 4,931 yang lebih besar dari nilai minimum yang ditentukan sebesar 1,96 dan nilai $p$-value sebesar 0,000 lebih kecil dari nilai maksimum yang ditentukan sebesar 0,05, yang berarti semakin baik dan besar financial capability seseorang maka semakin baik dan besar juga tingkat financial satisfaction seseorang. Indikator yang paling berpengaruh adalah indikator tentang orang tidak mengalami kesulitan dalam pengeluaran, serta melakukan pembayaran tagihan tepat waktu. 


\section{PENUTUP}

Berdasarkan hasil dari analisis data yang ada, maka dapat disimpulkan bahwa 1) Terdapat pengaruh financial behavior terhadap financial satisfaction. 2) Terdapat pengaruh financial attitude terhadap financial satisfaction. 3) Terdapat pengaruh financial capability terhadap financial satisfaction. Dalam penelitian ini terdapat beberapa keterbatasan yaitu 1) Dikarenakan keterbatasan waktu dan biaya, maka jumlah dari responden yang diperoleh pada penelitian ini cukup. 2) Variabel independen yang digunakan dalam penelitian ini hanya berfokus pada tiga variable yaitu financial behavior, financial attitude, dan financial capability. Berdasarkan hasil penelitian ini, maka peneliti akan memberikan beberapa saran yang dapat diuraikan sebagai berikut, 1) Untuk peneliti selanjutnya, disarankan untuk cakupan wilayah pengmbilan sampel diperluas. 2) Untuk peneliti selanjutnya, disarankan untuk menambah jumlah responden yang akan dijadikan sebagai sampel agar hasil penelitian bisa menjadi lebih akurat dan relevan. 3) Untuk peneliti selanjutnya, disarankan untuk menggunakan variabel independen yang lain seperti financial knowledge, financial stressor, financial solvency, financial socialization, childhood consumer experience, financial literacy, dan income 4) Untuk masyarakat (khususnya masyarakat Riau) disarankan untuk berusaha mempunyai perilaku keuangan yang baik berupa menyisihkan uang untuk menabung setiap bulan, dan berusaha untuk selalu membayar tagihan tepat waktu agar dapat mencapai tingkat kepuasan keuangan yang tinggi.

\section{DAFTAR PUSTAKA}

Arifin, A. Z. (2018). Influence Factors toward Financial Satisfaction with Financial Behavior as Intervening Variable on Jakarta Area Workforce. European Research Studies Journal, 21(1), 90-103.

Chandra, J. W., \& Memarista, G. (2015). Faktor-Faktor yang Mempengaruhi Financial Satisfaction pada Mahasiswa Universitas Kristen Petra. FINESTA, 3(2), 1-6.

Irwandi, Firli (2020). The Role of Financial capability as Education and Financial Satisfaction Mediator in indonesia student studying in the netherland.

Joo, S. \& Grable, J.E. 2004. An Exploratory Framework of the Determinants of Financial Satisfaction. Journal of Family and Economic Issues 25(1): 25-50.

Sahi, S. K. (2013). Demographic and socio-economic determinants of financial satisfaction. International Journal of Social Economics, 40, 127-150. doi:10.1108/03068291311283607

Taylor, M. 2011. Measuring financial capability and its determinants using survey data. Social Indicators Research 102(2): 297-314

Toscano, E.V., Amestoy, V.A. \& Del Rosal, R.S. 2006. Building Financial Satisfaction. Social Indicators Research 77(2): 211-243.

Veenhoven, R (2011). Greater happiness for a greater number: is that possible? if so, how?. Published in: Sheldon, K.M., Kashdan, T.B. \& Steger, M.F. (Eds.) Designing Positive Psychology: Taking Stock and Moving Forward. New York: Oxford University Press.

Xiao, J. J. (2008). Handbook of Consumer Finance Research. New York, NY: Springer Science,Business Media, LLC

Yulianti, N., \& Silvy, M. (2013). Sikap Pengelola Keuangan dan Perilaku Perencanaan Investasi Keluarga di Surabaya. Journal of Business and Banking, Vol. 3, No.1, pp. 57-68.

Zimmerman, S. L. (1995). Understanding family policy: Theoretical approaches (2nd ed.). Sage. 